\title{
Perceptions of health promoters about health promotion programmes for families with adolescents orphaned as a result of AIDS in the rural Hammanskraal region in South Africa
}

\author{
Authors: \\ Maseapo P. Mthobeni ${ }^{1}$ \\ Mmapheko D. Peu ${ }^{1}$ \\ Affiliations: \\ ${ }^{1}$ Department of Nursing \\ Science, University of \\ Pretoria, South Africa \\ Correspondence to: \\ Portia Mthobeni \\ Email: \\ portia.mthobeni@vodamail. \\ co.za \\ Postal address: \\ PO Box 17218, Witbank \\ 1035, South Africa \\ Dates \\ Received: 12 Jan. 2012 \\ Accepted: 19 Sept. 2012 \\ Published: 11 Feb. 2013 \\ How to cite this article \\ Mthobeni, M.P. \& Peu, M.D. \\ 2013, 'Perceptions of health \\ promoters about health \\ promotion programmes for \\ families with adolescents \\ orphaned as a result of AIDS \\ in the rural Hammanskraal \\ region in South Africa', \\ Health SA Gesondheid 18(1), \\ Art. \#648, 8 pages. http:// \\ dx.doi.org/10.4102/hsag. \\ v18i1.648

\section{Copyright:} \\ (C) 2013. The Authors. \\ Licensee: AOSIS \\ OpenJournals. This work \\ is licensed under the \\ Creative Commons \\ Attribution License.
}

South African communities are still greatly affected by the high rate of infection with HIV or who are living with AIDS, mirrored in the 2008 overall national HIV prevalence of $29.3 \%$ (UNAIDS 2010:10). In addressing the challenge, the health system is dependent on community care level workers such as caregivers to render health promotion and education in the homes and communities. The caregivers based in the communities are the ones with first-hand information on what is needed for the success of health promotion programmes. This study, aimed at exploring the challenges faced by the health promoters, described their perceptions regarding a health promotion programme for families with adolescents orphaned as a result of AIDS. Data were collected on the purposively selected participants at the rural Hammanskraal region in South Africa and the research question: 'What is your perception regarding health promotion programmes for families with adolescents orphaned as a result of AIDS' was asked and discussed by participants in a focus group interview. Data were analysed using the adapted Tesch method to organize and isolate the main categories, sub-categories and themes. The following main categories were isolated: attitudes of adolescents, effectiveness of home visits, need for health education and limited resources. Based on the findings, it was therefore recommended that health care planners assist in the improvement of health promotion and education by using the community and national media, providing information material and providing access to the internet in order to allow more people, including young people, to access the information.

Suid-Afrikaanse gemeenskappe word steeds grootliks beïnvloed deur die hoë vlak van MIV en vigs, soos weerspieël in die algehele nasionale MIV-syfer in 2008 van 29.3\% (UNAIDS 2010:10). In die aanspreek van hierdie uitdaging is die gesondheidstelsel afhanklik van gemeenskapsorgwerkers om gesondheidsbevordering en -opleiding aan huise en gemeenskappe te voorsien. Die versorgers wat in die gemeenskap werk, het eerstehandse inligting oor wat nodig is om die sukses van programme vir gesondheidsbevordering te verseker. Hierdie studie, wat ten doel het om die uitdagings van gesondheidspromotors te verken, beskryf hul persepsie ten opsigte van 'n gesondheidsbevorderingsprogram vir families met adolessente wat wees gelaat is as gevolg van vigs. Data is op die doelbewus geselekteerde deelnemers in die landelike Hammanskraal-streek in Suid-Afrika ingesamel en die volgende navorsingvraag is in 'n fokusgroep-onderhoud gevra en bespreek: 'Wat is jou persepsie oor die gesondheidsbevorderingsprogram vir families met adolessente wat ouerloos gelaat is as gevolg van MIV en vigs?' Die data is met behulp van die aangepaste Tesch-metode geanaliseer om die hoof- en sub-kategorieë, asook die temas te organiseer en isoleer. Die volgende hoof-kategorieë is uitgesonder: die houdings van adolessente, die doeltreffendheid van huisbesoeke, die behoefte aan gesondheidsopvoeding en beperkte hulpbronne. Gebaseer op hierdie bevindinge is die aanbeveling dat die gesondheidsorgbeplanners bydra tot die verbetering van gesondheidsbevordering en -opvoeding deur die gebruik van gemeenskapsen nasionale media, die beskikbaarstelling van inligtingsmateriaal en die voorsiening van internet om meer mense, insluitende jongmense, die geleentheid te bied om toegang tot die inligting te verkry.

\section{Introduction}

\section{Problem statement}

Providing health promotion in the communities is one of the many strategies that were introduced by the Government of South Africa in an attempt to combat the increasing numbers of people 
living with HIV and AIDS. However Peu, Van Wyk and Botha (2008:16) did acknowledge the fact that there were no formal written health promotion guidelines for families with adolescents orphaned as a result of AIDS. The same study reaffirms that lack of health resources such as health care services, lack of information on health care and poor access to health care services makes health promotion inevitable (Peu et al. 2008:16), hence the study of this nature was needed to accumulate adequate information from the sole beneficiaries of the programme; to assist in closing the health promotion gap and render the effective health promotion to the families with adolescents orphaned as a result of AIDS.

\section{Aims of the study}

This study aimed at exploring and describing the challenges met by the health promoters whilst rendering health promotion to the communities. The findings of this study will therefore assist in improving and developing health promotion guidelines for families with adolescents orphaned as a result of AIDS.

\section{Trends}

South Africa is rated as having the second highest orphan rate in the sub-Saharan region with an estimated 1900000 in 2009, led by Nigeria at 2400000 (Avert Stats 2009). The proportion of orphanhood in South Africa had shown to increase faster amongst children after the age of 12 years, which marked the beginning of the adolescent stage (Doctor \& Radasi 2007). Studies had shown a steady but increasing trend of orphans in the North West Province as compared to the higher rates in KwaZulu-Natal and Eastern Cape (ibid. 2007). However, it is alarming to learn that orphaned children are more likely to contribute to high rates of not going to school (ibid. 2007); fall under duress due to the loss of a parent or even an ailing parent, endure economic hardship, malnutrition and illness, and increased risk of abuse (Maqoko \& Dreyer 2007:718). A health care need was emphasized as the major need for orphaned adolescents in the study conducted by Peu et al. (2008:23) hence the study of this nature.

\section{Research objectives}

The following objective guided the research process: to explore and describe the perception of health promoters on health promotion programme for families with adolescents orphaned as a result of AIDS.

\section{Definition of key concepts}

The following operational definitions are discussed: adolescents; health promotion; health education; perception and orphans.

Adolescents: is the process of developing from child into an adult between the ages of 10 and 17 years (Peu et al. 2008: 16).

Health promotion: defined by O'Donnel as 'the science and art of helping people to change their lifestyle and move towards a state of optimal health' (Edelman \& Mandle 2000:16). World Health Organization (WHO) 1987:12 views health promotion as 'a unifying concept for those who recognise the need for change in the ways and conditions of living, in order to promote health' (Dennil, King \& Swanepoel 2007:122). In addition, health promotion is also defined as the process of enabling people (individuals) to increase control over the determinants of health, and thereby improve it' (Dennil et al. 2007:122). In this study, the art of helping people to change their lifestyle will be directed at families with adolescents orphaned as a result of AIDS.

Health education: is defined by Tone and Tilfort 'as any intentional activity which is designed to achieve health or illness, related learning in an individual's capability or disposition' (cited in Dennill et al. 2007:149). The activity will assist the individual in attaining the state of good health.

Perception: is an interpretation or impression based on one's understanding of something (Thompson 1996:1014). In this study, the health promoter's impression or interpretation is explored and described.

Orphan: is defined by United Nations as a child who has lost one or both parents (Avert 2009). In this study, the loss will be due to HIV and AIDS-related diseases.

\section{Significance of the study}

There are possible factors that seemed to constrain the effective rendering of health promotion services to the growing trends of families with adolescents orphaned as a result of AIDS. The study aims to explore the view as expressed by the executor of health promotion in the community on the challenges they face whilst rendering health promotion services to these families. The results of this study will assist health planners in closing gaps in health promotion programmes to enhance their efficiency for their recipients.

\section{Literature review}

South Africa has been recorded as the world's largest population living with HIV, as UNAIDS estimated 5.7 million people are living with HIV, more than $3 \mathrm{~m}$ of them being women and about 280000 being children aged 0-14 years (UNAIDS, SA 2010: 20). According to the ASA model 2003, over 500000 people were newly infected with HIV in 2009, and nearly 400000 people died of AIDS-related illnesses (UNAIDS, SA 2010:11). Therefore, health promotion is seen as a strategy that attempts to relieve the burden of diseases on the presently overloaded health system in South Africa. Hence, the South African government invited all the stakeholders, from governmental and non-governmental organisations as well as communities, to participate in the rendering of health promotion in the home-based care sector in order, amongst other objectives, to prevent health complications (Department of Health 2001; Peu, van Wyk \& Botha 2008:15). The Home Based Community Care and Support reported 411867 orphans and vulnerable children in 2008 and 2009 and 449732 children in the first three quarter of 2009 (UNAIDS, SA 2010:45). Furthermore, there 
is an increasing trend of orphans with one or both parents deceased. This is now estimated at $1.5 \mathrm{~m}$ to $3 \mathrm{~m}$ (UNAIDS, SA 2010:46).

Health promotion plays a major role in rendering healthcare to families and communities, especially to the vulnerable groups. The SA Country Progress Report noted that the country needed five times the number of available social workers just to deal with the orphans and vulnerable children (UNAIDS, SA 2010:33). With the increasing rate of children who are orphaned as a result of AIDS, health promoters are faced with the challenge of rendering health care to the families with adolescents orphaned as a result of AIDS. In promoting a healthy lifestyle, campaigns that will empower communities with the self-help skills and knowledge necessary for proactive community participation in health promotion behaviour are needed, especially in families with adolescents orphaned as a result of AIDS. A healthy life style in respect of HIV and AIDS-affected families would involve, amongst other things, the promotion of eating nutritious food, physical exercise, and avoiding activities that may lead to opportunistic infections and re-infection by HIV.

Estimates from the South African National HIV prevalence rates of 2008 (released 2009) amongst antenatal attendees stand at $29.3 \%$, which represents a stable number compared to 2006 and 2007 at $29.0 \%$ and $29.4 \%$ respectively (UNAIDS, SA 2010:10). The South African provincial reports on HIV prevalence amongst antenatal clinic attendees do show a report on four provinces recording higher prevalence than the national average of $29.3 \%$ (UNAIDS, SA 2010:23). The KwaZulu-Natal province still maintains its highest rate of 39.5\% in 2009, Mpumalanga 34.7\%, Free State 30.1\%, and North West $30.0 \%$ (Sastats 2009). It is, however, disturbing that the infection rate in the North West province remains unchanged over a period of 3 years. The infection rate ranges from $29.0 \%$ in 2006, 29.0\% in 2007 and $30.0 \%$ in 2008 (UNAIDS, SA 2010:25), which prompted the research question to explore the challenges and barriers of the people rendering health promotion services. The purpose of this study was to explore and describe the experiences of health promoters in their field of work whilst rendering health promotion to orphaned adolescents who are not only affected by the loss of parents due to HIV and AIDS, but also have to thrive in life whilst taking care of their siblings.

According to Stanhope and Lancaster (2008:679) it is during the teen years that a young girl learns the basic health promoting behaviour that she will carry into adulthood. Orphaned adolescents find themselves compelled to implement health promotion activities at home without prior training. It is the responsibility of health promoters to provide a comprehensive health promotion strategy to teach and endorse correct health promotion activities in such cases. Healthy attitudes and practices that include regular exercise and mental health promotion must be incorporated at early ages to have lasting positive benefits throughout a woman's (man's) life (Allender \& Spradley 2005:679). It is during the teen years that the prevention strategies such as providing health and safety education and encouraging both males and females to keep their immunisation up-to-date are learned (Allender \& Spradley 2005:693). The significance of this study is to identify the possible factors that constrain the effectiveness of a health promotion programme and to assist the health planners to close any possible gaps regarding the effectiveness of health promotion, especially in this new growing trend of orphaned adolescents.

\section{Research method and design Design}

The research methodology was qualitative in nature. Focus group interview was the method used to collect a rich descriptive data from the study participants. The researcher chose focus group methods for its ability to obtain many viewpoints of many individual in a short time (Polit \& Beck 2008:395), whilst observing, describing and documenting the situation in the setting of the study participants (Polit \& Beck 2008:326, 752).

\section{Research population and sampling}

The population of this study consisted of government and non-governmental health promoters, males and females working under the North West Department of Health around rural Hammanskraal in South Africa, directly and indirectly involved in promoting health care to families with adolescents orphaned as a result of AIDS. A total of ten participants, which included four males and six females with ages ranging from 19-38 years, were purposively selected as they met the criteria of the population required. All participants had high school education and two had tertiary education (Table 1). Two people assisted in handpicking the study participants, namely the health promotion coordinator from the hospital in Hammanskraal, and the social worker working closely with the health promoters involved in the families with adolescents orphaned as a result of AIDS.

\section{Data collection methods}

Data were collected at the participants' area of work, and the researcher facilitated the focus group interviews. During the first briefing session, participants were educated on their ethical rights, the purpose of this research and the process of data collection. The information leaflet and the consent forms were presented on the same day for the participants to read and sign at home and bring to the next meeting as arranged.

TABLE 1: Demographic presentation of participants.

\begin{tabular}{llll}
\hline Criterion & Characteristics & $\boldsymbol{f}$ & $\mathbf{\%}$ \\
\hline Health promoters & Caregivers & 6 & 60 \\
& Non-caregivers & 4 & 40 \\
Gender & Female & 6 & 60 \\
& Male & 4 & 40 \\
Educational level & High School Education & 8 & 80 \\
& Tertiary education & 2 & 20 \\
Age & $19-29$ years & 8 & 80 \\
& $30-40$ years & 2 & 20 \\
\hline
\end{tabular}

$f$, Frequency. 
Following the briefing session, two focus group discussions were conducted with the study participants on different days. The research question 'what is your perception regarding health promotion for families with adolescents orphaned as a result of AIDS?' was asked and the participants elaborated on their feelings. The interviews were conducted for 40-60 minutes with the researcher probing, following up on clues and constantly encouraging the participants to continue with the discussion until no new data were elicited from the participants. A total attendance of ten participants on both interviews was maintained as the researcher was in constant communication with them on their availability. The researcher used the tape recorder to record the interview and kept field notes, which were then transcribed and analysed.

\section{Data analysis}

Data were analysed using the adapted Tesch version as described in De Vos (2005:334) and Cresswell (2003:192). Tesch method provides eight detailed guidance for the coding process which aided the researcher in a systematic process of analysing textual data (Cresswell 2003:193). As the researcher collected data using the tape recorder, transcriptions of the interviews were done regularly and accurately according to the descriptive method. Both the researchers and the senior researcher discussed and agreed on the categories, sub-categories and themes to be included in the analysis. Direct quotations were used to support every category and sub-category as themes.

The researcher read through the transcribed information and got a sense of what was said and made a list of topics whilst reading through the transcription. The researcher then clustered together the similar topics into columns, and arranged them as major topics and unique topics. The researcher, using a highlighter, coloured the topics with similar meaning with the same colour, finding the most descriptive word for those topics, turning them into categories. Each category was assembled with the topics similar to the category as sub-categories, and each subcategory with a theme that represented the quote of exact words from the transcription. The supervisor and the researcher met and discussed the findings, and reached a consensus about the categories, subcategories and themes that have been identified.

\section{Context of the study}

This study was conducted in the rural Hammanskraal region situated in the North West Province. The study participants are working for the non-profit organization Sunrise Hospice Centre based in the region and the interviews were conducted at the hospice centre.

\section{Results}

Four categories and fourteen sub-categories that emerged from the data analysis assisted the researcher in exploring and describing the perception of health promoters regarding health promotion programmes for families with adolescents orphaned as a result of AIDS. The four categories identified in this regard were attitude of adolescents, effectiveness of home visits, need for health education and limited resources (Figure 1).

\section{Attitude of adolescents}

Attitude of adolescents emerged as a category with ignorance, resistance and lack of motivation as sub-categories. The adolescents and the community at large showed no interest in the participants' attempt to educate them and provide health promotion activities for them. Adolescents could not associate themselves with the health promoters, as they already knew what they were going to say and therefore ignored them when approached:

'... people are so used to our services they tend to ignore us.' (Participant 3, Female, Health Promoter, 23 years, Matric)

The adult community is also still ashamed to talk about safe sexual activities in the presence of their children, which is

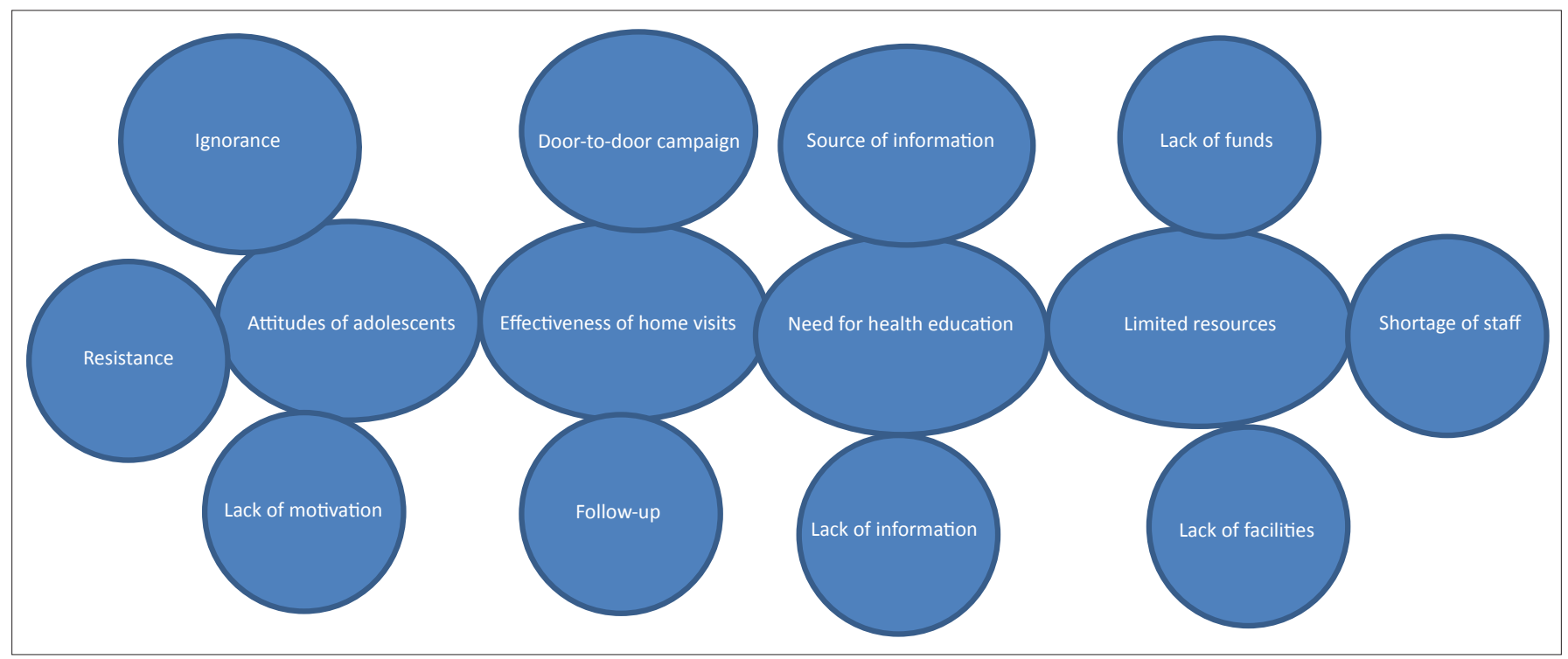

FIGURE 1: Results on the perception of health promoters. 
rather worrying, and applies especially to the religious community:

'We are still met with a lot resistance in our community, especially in our churches...' (Participant 5, Female, Health Promoter, 29 years, Matric)

The participants are working in this type of conditions, and earn next to nothing, which puts a strain on their commitment to perform their duties:

'...no increment on what we are earning, any incentives or bonuses. This is so discouraging to us and we are not motivated at all.' (Participant 1, Male, Health Promoter, 25 years, Matric)

\section{Effectiveness of home visits}

The effectiveness of home visits were identified with the following sub-categories: door-to-door campaigns, and follow-up. The participants took part in door-to-door campaigns as part of their services to the community where they issue information leaflets and health education to the families, and this elicited good results:

'People do get the message and we find a number of people coming to the centre for more.' (Participant 3, Female, Health Promoter, 23 years, Matric)

During these door-to-door campaigns, participants identify cases that need follow up, refer cases that need professional help and provide health advice to those who welcome it. They also conduct daily home visits where they render health care to the frail and ill clients. The participants' main challenge in doing home visits and follow up was lack of transport, which made their clients lost to follow-up and became worse in their health state:

'We never find time to go back to check on clients due to lack of transport.' (Participant 2, Male, HIV Counsellor, 28 years, Matric)

\section{Need for health education}

Lack of information and source of information emerged from this category need for health education. The participants felt that young people lacked information on HIV and AIDS as is evident that there are a lot of pregnant teenagers in the community:

'...What worries me is the fact that they still become pregnant even after the health talks.' (Participant 5, Female, Health Promoter, 29 years, Matric)

However the participants regard themselves as the source of information since the young people come to them whenever they need HIV and AIDS information. They felt proud and important that they are contributing to the wellbeing of the community:

'Some young people do use us as their source of information. They do ask questions regarding HIV and AIDS; some are using it for their school work.' (Participant 9, Male, 38 years, Health Care Provider, Diploma)

Participants reckoned that an information corner from which the communities - especially young people - could access information without being associated with community health workers, could be beneficial in distributing the health education materials.

\section{Limited resources}

Limited resources are described as lack of funds, shortage of staff and lack of facilities. Participants expressed their concerns on the sustainability of the health promotion programme. There are periods where the centre runs out of funding and the participants have to go without their monthly payments, which leaves them financially distressed and hungry:

'At times there is a delay in funding which leads to late payment or even no payment to us as health promoters'. (Participant 4, Female, Health Care Provider, 28 years, Diploma)

They felt that the workload is increasing and requires a larger workforce adequately to cover the burden of care. In addition, they requested that a doctor be appointed at their centre to minimize the referral route to government clinics:

'For the programme to be successful, we need to address the staff shortages...' (Participant 7, Male, Health Promoter (working as an administrator, 32 years, Matric)

'...If we had our own doctor who will diagnose, prescribe and manage our clients at the centre, people will get relevant treatment for their conditions'. (Participant 4, Female, Health Care Provider, 28 years, Diploma)

The participants added the need for resources such as a daycare and youth centre, so that those adolescents who are left to care for their siblings could leave them at the centre whilst they go to school or work:

'We also need the day-care centre for children'. 'I think if we had a youth centre, we will attract a lot of young people.' (Participant 6, Female, Health Promoter, 19 years, Matric)

\section{Ethical consideration}

Ethics is the branch of philosophy that deals with morality (Burns \& Groove 2005:62). This study was conducted for academic purposes; ethical clearance to conduct this study was obtained from the University of Pretoria Research Ethics Committee. Permission to conduct the study was also obtained from the North West Department of Health.

Regarding participants this study used the following principles to protect them from ethical misconducts: beneficence, respect for human dignity and justice. Participants' rights were discussed in the first contact meeting as they were given a full preview of the study stating the purpose, objectives and the research method to be used. Following this debriefing process, an information leaflet with the consent forms was given to participants to read, understand and sign at home. Participants were advised to withdraw at any point, should they feel emotionally drained. The purpose of this study was to explore and describe the perception of health promoters in rendering health promotion services. The outcome of this study will benefit the recipients of health promotion services, and specifically those families headed by adolescents orphaned as a result of AIDS.

Confidentiality was maintained throughout the research process. Participants were treated fairly and with respect and dignity. Those who chose not to participate were treated 
with respect and without discrimination. The involvement of the supervisor was explained to the participants in order for them to give a full, informed consent. The data collected were saved on the audio cassettes and in the field notes, which were only accessible to the researcher and the senior researcher (Polit \& Beck 2008:173).

\section{Trustworthiness}

Trustworthiness refers to the degree of confidence qualitative researchers have in their data using the criteria of credibility, dependability, confirmability and transferability (Polit \& Beck 2008:196). The strategies applied in ensuring trustworthiness are outlined (Table 2).

\section{Discussion \\ Outline of the results}

Four categories and 14 sub-categories that emerged from the data analysis assisted the researcher in exploring and describing the perception of health promoters regarding health promotion programmes for families with adolescents orphaned as a result of AIDS. The four categories identified in this regard were attitude of adolescents, effectiveness of home visits, need for health education, limited resources. The findings of this research concur with findings of other researchers.

The participants experienced ignorance from the young people when provided with health education about HIV and AIDS. They met a lot of resistance from the community at large, especially religious people. Talking about safe sex, condom use and the transmission of HIV was regarded as a taboo to their religion and by older people. Similarly, Norman et al. (2009:141) identified ignorance and misconception about the disease as the two primary reasons for discrimination towards people living with HIV and AIDS. Wang, Meier, Shah, and Li (2007:47) identified six activities to provide health education, namely distribution of educational materials; showing of educational videos; delivery of lectures; facilitation of peer group discussions; and provision of reproductive health services and counselling. The counsellors and health workers are experiencing stigma and resistance surrounding HIV and AIDS enacted by the community whilst caring for HIVpositive patients (Delobelle et al. 2009:1067). Also, in a study conducted by Dhavanna-Maselesele, Lalendle and Useh (2007:18) parents and church leaders were rated amongst the least-consulted sources of information, mainly because most parents and church leaders do not create an environment that allows for free discussion of sex-related issues, including HIV and AIDS.

Doing the door-to-door campaign in the community assisted the participants to identify families with health needs and affected families headed by children and adolescents. Participants were faced with challenges such as increased workloads and transport problems when supposed to follow up on their clients. Tolle (2009:669) recommended that an extensive outreach programme utilising the communitybased services should be a priority to regularly assess the families' unmet needs. Similar studies confirmed that home visits are a necessity to the under-resourced communities with limited access to healthcare services (Mtshali 2005:9). The purpose of home healthcare nurses is to provide direct clinical and preventive care to ill and/or injured patients in a home setting (Williamson 2007:133). The study on the Iranian community reveals that male community workers were charged with activities mainly outside the health houses, such as making follow-up visits to patients and identifying them in surrounding villages (Bulletin of the World Health Organization 2008:586). Williamson (2007:145) further advises homecare nurses in the field that it is imperative that communication be effective in order to keep in touch with clients.

During their services in the community, participants noticed a lack of information amongst young and older people as evidenced by the increased teenage pregnancy. Young people would ask questions from the participants when given assignments on HIV and AIDS at school. For the same reasons, participants issued HIV and AIDS information materials to the young people to read on their own to gain information. Similar studies reported limited information concerning HIV knowledge and attitude towards HIV testing in underserved communities (Djokic et al. 2009:23).

TABLE 2: Strategies to establish trustworthiness.

\begin{tabular}{lll}
\hline Strategy & Criteria & Application \\
\hline Credibility & $\begin{array}{l}\text { Prolonged engagement } \\
\text { Persistent observation }\end{array}$ & $\begin{array}{l}\text { Two sessions were held for } 45-60 \text { minutes per session with the participants on different days. } \\
\text { The tape recorder was used to record all data during the interviews, whilst the researcher collected field notes on } \\
\text { the nonverbal communication and/or signals and gestures during the interview. } \\
\text { Multiple data sources were used to validate the conclusion. } \\
\text { Triangulation }\end{array}$ \\
& The same researcher collected data on all occasions to confirm consistency. \\
& The researcher constantly checked with the participants after transcription. \\
& Peer debriefing & $\begin{array}{l}\text { The results were taken to participants for confirmation post analysis. } \\
\text { The researcher used own peers to discuss issues of concern and the senior researcher was directly and/or fully } \\
\text { supervising the process of data collection. }\end{array}$ \\
Dependability & $\begin{array}{l}\text { Data were recorded on tape and transcribed, in addition to the field notes. } \\
\text { The researcher and the supervisor reached consensus on the accurate description of findings and results. }\end{array}$ & $\begin{array}{l}\text { The use of field notes, the interview report, and the taped data confirmed the neutrality of the study. } \\
\text { The presence of the senior researcher to supervise the data collection confirmed the objectivity of the study. }\end{array}$ \\
Confirmability & Follow-up visits to collect more data from the participants until no new information was elicited. \\
& The use of purposive sampling to select participants who have knowledge of the topic under study. &
\end{tabular}


The study conducted of a rural African population confirmed that young people were at risk of adolescent pregnancy and sexually transmitted deseases, with a low incidence of condom use (Ross 2007:1943). Also the study by Djokic et al. (2009:23) reported that Black women are at a high risk for contracting HIV, as related to risk behaviour of their sexual partner or by having multiple partners. However, the majority $(75.0 \%-85.0 \%)$ of the surveyed community wanted to learn about HIV risk factors, testing, treatment choices and AIDS-related disease through pamphlets, videos, classes or neighbourhood meetings (Djokic et al. 2009:25). The researchers concluded that exposure to branded messages was significantly more likely to be effective in adolescents who are at a higher risk of acquiring HIV and AIDS (Yoo et al. 2005:396). In a similar study, the most commonly reported source of information for both male and female students was the media (newspapers, magazines and television), friends and clinics (James, Reddy \& Jinabhai 2004:266).

Delayed funding impacted negatively on the participants' morale and motivation to work, as they are greatly dependant on the stipend they receive monthly to support their families. Participants also identified resources such as staff, and facilities such as a day-care centre and youth centre, which could add value to health promotion in the community. Participants reckoned that peer education at the youth centre would attract young people and encourage their participation. In similar studies participants reported being overworked, demoralised and emotionally distressed due to seeing patients with incurable diseases deteriorate over time (Delobelle et al. 2009:1066). The researchers concluded that, in order to retain personnel, very serious attention needs to be given to the needs of nurses regarding salaries, workload and working conditions, as well as to the recognition of nurses for their contribution (Selebi \& Minnaar 2007:59). In addition and by virtue of their positions, managers have the ability to motivate subordinates by empowering them occasionally with increasing responsibility and implementing a rewards system that reflects an individual and collective value system (Marquis \& Huston 2006:458-459).

The World Health Organisation acknowledges the fact that a lack of long-term sustained funding threatens efforts to achieve universal access to HIV prevention, treatment and care (WHO 2008). Programme sustainability is a process of intervention to continue to deliver benefits or health gains beyond the initial funding or demonstrating the project stage (Herman and Saxena \& Moodie 2005:20). The staff shortage was regarded as the most urgent threat to the early success of the ART treatment (Van Oosterhood et al. 2007:1245), whilst infrastructure was seen as a long-term investment in caring for the HIV and AIDS clients (Tolle 2009:669).

A children's day-care centre at the hospice facilities has proven to be a necessity for different needs as observed at Trinity Hospice and Palliative Care Services. There is a link between children orphaned as a result of AIDS and a lower school enrolment rate (Cluver, Gardner \& Operario 2009:735). The relationship reveals the overall school attendance of children orphaned as a result of AIDs as $93.9 \%$, compared to the $97.1 \%$ of other orphaned or non-orphaned children's overall school attendance (Cluver et al. 2009:735). Given this rate, it is vital to have a day-care centre for children aged 0-6 years for the child-headed family with young siblings, an after-school programme for older children, and supportive care for chronically ill children (Heymann \& Kidman 2009:39). These measures would assist in poverty alleviation, as the older family members will go to work or school to be able to take care of the family (Hermann \& Kidman 2009:39).

\section{Limitation of the study}

The study was conducted and limited to health promoters in a rural area, and the results cannot be generalised to all health promoters, especially those in urban areas. The sample size used in one province cannot be generalised to health promoters of other provinces. However, health policy makers could make use of these findings to improve the distribution of resources, and to attend to the challenges faced by health promoters in the communities as part of establishing an effective health promotion programme.

\section{Recommendations}

Based on the findings of this study, it was therefore recommended that health care planners assist in the improvement of health promotion and education through community and national media, availability of information material and easy access via the Internet in order to attract more people, including young people, to access information. Equal distribution of resources including medicine, equipment and finances should be maintained in order to ensure uninterrupted services. Availability of infrastructure for people living with HIV and AIDS and other chronic diseases, such as terminally ill cancer patients and any form of paralysed clients who need specialised care, should form the basis of the intervention. The establishment of improved peer education programmes that are accessible to all communities should be considered.

\section{Conclusion}

A qualitative study was conducted and followed an exploratory, descriptive and contextual design. Based on the research questions, the results of this study, namely attitude of adolescents, effectiveness of home visits, need for health education and limited resources, demonstrated that multiple factors are responsible in limiting the effective rendering of health promotion; hence of our country struggles in reducing the HIV infection rate. Even though these results cannot be generalised to all the provinces, it is clear that there is still a challenge in the rollout of health promotion by the community health care workers. By considering new alternatives, namely additional resources and working with the young people of our communities, effective health promotion programmes could be developed. 


\section{Acknowledgements Competing interest}

The authors declare that they have no financial or personal relationships which may have inappropriately influenced them writing this article.

\section{Authors' contributions}

M.D.P. (University of Pretoria) was responsible for structuring, editing and supervising the writing of this article whilst M.P.M. (University of Pretoria) was responsible for writing this article.

\section{References}

Aids Orphans, viewed on 09 February 2012, from http://www.avert.org

Allender, J.A. \& Spradley, B.W., 2005, Community Health Nursing: Concept and Practice, 6th edn., Lippincott, Philadelphia. PMCid:1081367

Clark, M.J., 2008, Community health nursing: Advocacy for population health, 5th edn., Pearson Education, New Jersey.

Cluver, L., Gardner, F. \& Operario, D., 2009, 'Poverty and psychological health amongst AIDS-orphaned children in Cape Town, South Africa', AIDS Care 21, 6, 732-741. http://dx.doi.org/10.1080/09540120802511885, PMid:19806489

Cresswell, J.W., 2003, Research design: Qualitative, quantitative and mixed methods approaches, 2 nd edn., Sage, CA.

Doctor, H.V. \& Radasi, Z.M., 2007, Orphans, schooling and medical aid coverage in the era of HIV/AIDS in South Africa, University of Western Cape, South Africa.

Davhanna-Masesesele, M., Lalendle, L.L. \& Useh. U., 2007, 'Knowledge, attitudes and practices related to HIV/AIDS amongst learners in Vhembe district of Limpopo Province', Curationis 30, 3, 15-21.

Delobelle, P., Rawlinson, J.J.L., Ntuli, S., Malatji, I., Decock, R. \& Depoorter, A.M., 2009, 'HIV/AIDS knowledge, attitudes, practices and perceptions of rural nurses in South Africa', Journal of Advanced Nursing 65, 5, 1061-1073. http://dx.doi. org/10.1111/j.1365-2648.2009.04973.x, PMid:19399982

Dennil, K., King, L., \& Swanepoel, T., 2007, Aspects of primary health care: Community health care in Southern Africa, Oxford University Press, Cape Town.

De Vos, AS., Strydom, H., Fouche, C.B., \& Delport C.S.L., 2005, Research at grass roots: For the social science and human service professions, 3rd edn., van Schaik, Pretoria.

Djokic, D., Englund, J., Daum, R., Martin, R., Dozier, T., Potts, S. et al., 2009, 'HIV knowledge and attitudes toward HIV testing of south side Chicago housin authority residents', AIDS Patients Care and STDs 23, 1, 23-28. http://dx.doi. org/10.1089/apc.2008.0110, PMid:19183078

Edelman, C.L., \& Mandle, C.L., 2000, Health promotion: Throughout life span, 5th edn., Mosby, USA.

Heymann, J. \& Kidmann, R., 2009, 'Psychological and Socio-medical Aspect of HIV/ AIDS', Aids Care 21, 1, 34-42. http://dx.doi.org/10.1080/09540120902927593, PMid:22380977, PMCid:2903780

Herman, H., Saxena, S. \& Moodie, R., 2005, Promoting mental health: Concepts, emerging evidence, practice, WHO Publication, World Health Organisation Geneva.

James, S., Reddy, S.P. \& Jinabhai, C.C., 2004, 'Young people, HIV/AIDS/STIs and sexuality in South Africa: The gap between awareness and behaviour', Acta Paediatrica 93, 264-269. http://dx.doi.org/10.1111/j.1651-2227.2004.tb00718.x, PMid:15046286
Marquis, B.L. \& Huston, J.H., 2006, Leadership roles and management functions in nursing: Theory and application, 5th edn., Lippincott Williams \& Wilkins, Philadelphia.

Maqoko, Z. \& Dreyer, Y., 2007, 'Child-headed households because of the trauma surrounding HIV/AIDS, Department of Practical Theology', Hervormde Teologiese Studies 63(2), 718-721.

Mtshali, N.G., 2005, 'Conceptualisation of community-based basic nursing education in South Africa: A grounded theory analysis', Curationis 28, 2, 5-12.

Nebraska Department of Health and Human Services, 2007, Health Education to Racial/Ethnic Minorities in Nebraska: Strategic Plan, AA/EOE/ADA.

Norman, L.R., Abreu, S., Candelaria, E. \& Sala, A., 2009, 'The effect of sympathy on discriminatory attitudes toward persons living with HIV/AIDS in Puerto Rico: A hierarchical analysis of women living in public housing', AIDS Care 21, 2, 140-149. http://dx.doi.org/10.1080/09540120801932199, PMid:19229682

Peu, M.D., Van Wyk, N.C. \& Botha, A.D.H., 2008, 'Health promotion needs of Hammanskraal families with adolescents orphaned by HIV/AIDS', Health SA Gesondheid 13, 1, 14-28. http://dx.doi.org/10.4102/hsag.v13i1.254

Polit, D.F. \& Beck, C.T., 2008, Nursing research: Generating and assessing evidence for nursing practice, 8th edn., Lippincott, Philadelphia.

Rall, M. \& Meyer, S.M., 2006, 'The role of the registered nurses in the marketing of primary healthcare services as part of health promotion', Curationis 29, 3, 10-24.

Ross, D.A., Changlucha, J., Obasi, A.I.N., Todd, J., Plummer, M.L., Cleophas-Mazige, B. et al., 2007, 'Biological and behavioural impact of an adolescent sexual health intervention in Tanzania: A community-randomized trial', Epidemiology and Socia 21, 14, 1943-1955.

Rossouw, D., 2005, Intellectual tools: Skills for the human sciences, 2nd edn., van Schaik, Pretoria.

Selebi, C. \& Minnaar, A., 2007, 'Job satisfaction amongst nurses in a public hospital in Gauteng: 'It all about salaries', Curationis 30, 3, 53-61.

South Africa-2010 Country Progress Report-UNAIDS, viewed on 13 August 2011, from http://www.unaids.org.

South Africa HIV and AIDS Statistics, viewer on 13 August 2011, from http://www. avert.org/safricastats.htm

Stanhope, M. \& Lancaster, J., 2008, Community and Public Health Nursing, 7th edn. Mosby, USA.

Tolle, M.A., 2009, 'A package of primary healthcare services for comprehensive familycentred HIV/AIDS care and treatment programs in low-income setting', AIDS Care $14,6,663-672$.

Thompson, D. (ed.), 1996, Concise Oxford Dictionary of Current English, 9th edn., BCA, London.

Trinity Hospice and Palliative Care Service, viewed on 15 August 2010, from http:// www.trinityhospice.co.uk/brian-house/brian-house-faq/

Van Oosterhout, J.G., Kumwenda, J.K., Hartung, T., Mhango, B. \& Zijlstra, E.E., 2007, 'Can the initial success of the Malawi ART scale-up programme be sustained? The example of Queen Elizabeth Central Hospital, Blantyre', AIDS Care 19, 10, 1241 1246. http://dx.doi.org/10.1080/09540120701403358, PMid:17886172

Wang, B, Meier, A, Shah, I \& Li., 2007, 'The Impact of a Community-Based Comprehensive Sex Education Program on Chinese Adolescents' Sex-Related Knowledge and Attitudes', Journal of HIV/AIDS Prevention in Children \& Youth 7,2 43-64. http://dx.doi.org/10.1300/J499v07n02_04

Williamson, K.M., 2007, 'Home healthcare nurses' perceptions of empowerment', Journal of Community Health Nursing 24, 3, 133-153. http://dx.doi. org/10.1080/07370010701429512, PMid:17650984

World Health Organization, 2008, 'Iranian health houses open the door to primary care', Bulletin of the World Health Organization 86, 8, 585-586. http://dx.doi. org/10.2471/BLT.08.030808, PMid:18797612 PMCid:2649473

World Health Organization, 2008, 'Towards universal access: Scaling up priority HIV/ AIDS intervention in the health sector', WHO Publication, Geneva.

Yoo, H., Lee, S.H., Kwon, B.E., Chung, S. \& Kim, S., 2005, 'HIV/AIDS knowledge, attitudes, related behaviours and sources of information amongst Korean adolescents', Journal of School Health 75, 10, 393-399. PMid:16313510 